\title{
Study Day of Body Weight Gain
}

National Cancer Institute

\section{Source}

National Cancer Institute. Study Day of Body Weight Gain. NCI Thesaurus. Code

C119762.

The study day that a body weight gain assessment is performed. 